症例

膵管胆管合流異常に膵頭部癌を合併した 1 例

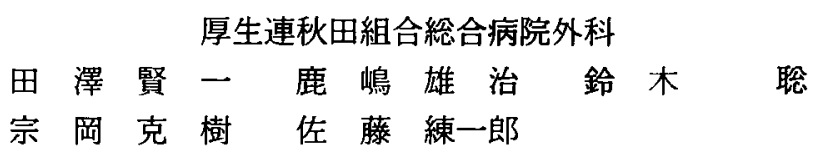

症例は, 48歳, 女性. 上腹部痛, 全身掻接感を主訴に来院, 精査にて IIa 型の脺管胆管 合流異常を合併した膵頭部癌を認めた。减黄目的に施行されたPTGBD（経皮経肝胆衰 ドレナージ）にて採取された胆汁中のアミラーゼ値は380IU/Lで，CA19-9值は10,000 IU/L 以上で, 胆汁細胞診は Class I であった，画像所見より，切除可能な膵頭部癌と診 断し, 脺頭十二指腸切除術を施行した. 切除標本の病理組織学的所見では, 膵頭部に径 $5 \mathrm{~cm}$ 大の高分化型管状腺癌を認め, 尾側の主脺管には慢性炎症に伴う膵管上皮の過形成 変化を認めた。

膵管胆管合流異常と膵頭部癌の合併例の報告は, 極めて少なく, 発癌との関連性は明 らかにされていないが, 膵管胆管合流異常症例においては, 膵病変の存在も念頭におき 対処すべきと考える。

索引用語：膵管胆管合流異常, 膵頭部癌, 慢性膵炎

緒 言

膵管胆管合流異常に合併する胆道癌の報告例は多く, 胆道系上皮に対する逆流脺液の暴露が, その発癌過程 に関与しているといわれているいー5).

一方, 膵管胆管合流異常と膵癌との合併例の報告は 少なく, 膵癌発生のメカニズムは, 未だ解明されてい ない.

われわれは，膵管胆管合流異常に膵頭部癌を合併し た1手術例を経験したので，文献的考察を加え報告す る.

患者：4藏, 女性.

主訴：上腹部痛, 全身播痒感。

家族歴：母親が脺臓癌で死亡（詳細不明）。

既往歴：精神分裂病 (平成 5 年 2 月発症)。アルコー 儿歴 $(-)$.

現病歴: 平成 6 年 2 月はじめより上腹部痛, 全身蛍 痒感が出現し, 同年 2 月17日当院内科を受診した. 初 診時, 腹部超音波検査にて脺頭部腫瘤, 主脺管の拡張, 肝内胆管の㹡張を認め，膵頭部腫場を疑い，精査目的 にて同日外科紹介入院となった。
入院時現症：身長 $155 \mathrm{~cm}$ ，体重 $50.5 \mathrm{~kg}$ ，全身皮商に 高度の黄染を認め, 臍上部に压痛を伴うクルミ大の腫 瘤を触れた。

入院時検査：末梢血中の白血球増多とビリルビン値 の上昇, 肝逸脱醭素の高值, 胆道系醉素の高値を訆め た。また，血清アミラーゼ值は331IU/L，尿中アミラー ゼ值は $939 \mathrm{IU} / \mathrm{L}$ と軽度の上昇を認めた。腫瘍マーカー

\section{表 1 入院時血液検査所見}

\begin{tabular}{lc|ll}
\hline WBC & $11,900 / \mathrm{mm}^{3}$ & T-Cho & $264 \mathrm{mg} / \mathrm{dl}$ \\
$\mathrm{RBC}$ & $398 \times 10^{4} / \mathrm{mm}^{3}$ & $\mathrm{Ch}-\mathrm{E}$ & $236 \mathrm{IU} / \mathrm{L}$ \\
$\mathrm{Hb}$ & $12.7 \mathrm{~g} / \mathrm{dl}$ & $\mathrm{FBS}$ & $127 \mathrm{mg} / \mathrm{dl}$ \\
$\mathrm{Ht}$ & $37.1 \%$ & $\mathrm{Na}$ & $132 \mathrm{mEq} / \mathrm{L}$ \\
$\mathrm{Plt}$ & $44.4 \times 10^{4} / \mathrm{mm}^{3}$ & $\mathrm{~K}$ & $4.2 \mathrm{mEq} / \mathrm{L}$ \\
$\mathrm{TP}$ & $6.6 \mathrm{~g} / \mathrm{dl}$ & $\mathrm{Cl}$ & $101 \mathrm{mEq} / \mathrm{L}$ \\
$\mathrm{Alb}$ & $4.3 \mathrm{~g} / \mathrm{dl}$ & $\mathrm{Ca}$ & $9.4 \mathrm{mg} / \mathrm{dl}$ \\
$\mathrm{T} \cdot \mathrm{Bil}$ & $16.5 \mathrm{mg} / \mathrm{dl}$ & $\mathrm{Mg}$ & $2.1 \mathrm{mg} / \mathrm{dl}$ \\
$\mathrm{GOT}$ & $157 \mathrm{IU} / \mathrm{L}$ & $\mathrm{IP}$ & $2.6 \mathrm{mg} / \mathrm{dl}$ \\
$\mathrm{GPT}$ & $103 \mathrm{IU} / \mathrm{L}$ & $\mathrm{BUN}$ & $4.5 \mathrm{mg} / \mathrm{dl}$ \\
$\mathrm{ALP}$ & $1.152 \mathrm{IU} / \mathrm{L}$ & $\mathrm{Cre}$ & $0.4 \mathrm{mg} / \mathrm{dl}$ \\
$\mathrm{LDH}$ & $360 \mathrm{IU} / \mathrm{L}$ & $\mathrm{CEA}$ & $4.0 \mathrm{ng} / \mathrm{ml}$ \\
$\gamma \cdot$ GTP & $1.976 \mathrm{IU} / \mathrm{L}$ & $\mathrm{CA} 19-9$ & $250 \mathrm{u} / \mathrm{ml}$ \\
$\mathrm{LAP}$ & $266 \mathrm{IU} / \mathrm{L}$ & AFP & $3.0 \mathrm{ng} / \mathrm{ml}$ \\
S-AMY & $331 \mathrm{IU} / \mathrm{L}$ & & \\
U.AMY & $939 \mathrm{IU} / \mathrm{L}$ & & \\
\hline
\end{tabular}

1996年11月12日受付 1997年4月15日採用 


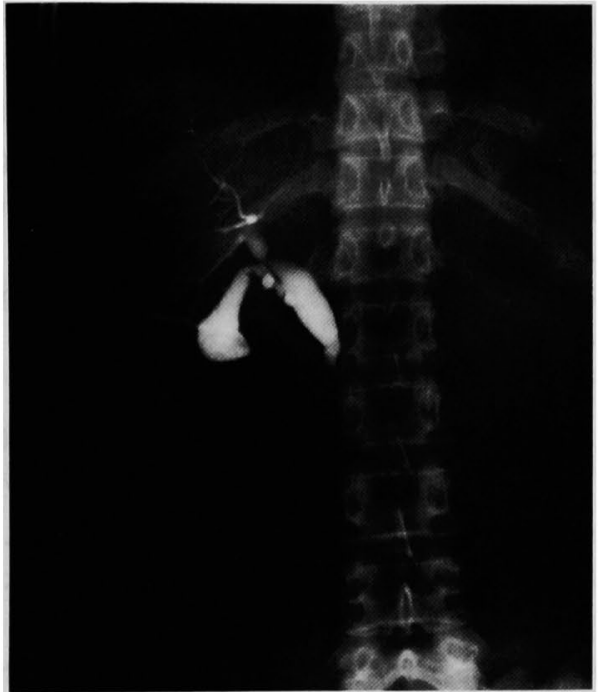

図 1 経皮経肝胆囊ドレナージ造影：下部総胆管に狭 窄像を認め，総胆管，肝内胆管に拡張像を認めた。

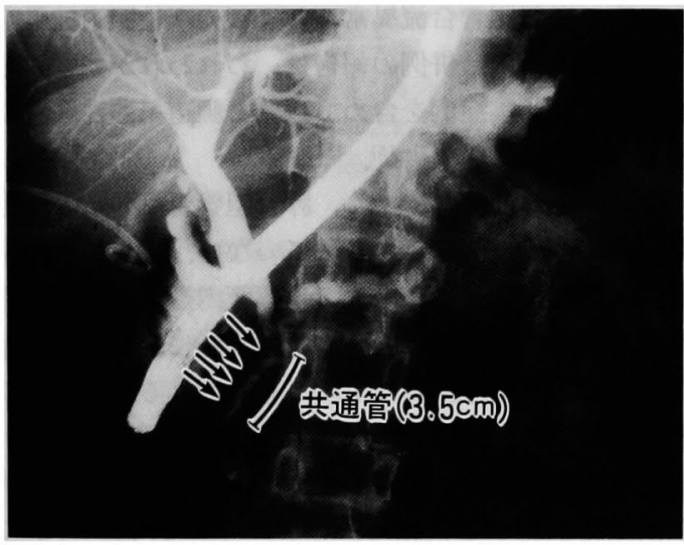

図 2 内視鏡的逆行性膵管胆管造影：膵頭部内に3.5 $\mathrm{cm}$ にわたり共通管を形成する膵管胆管合流異常 (IIa 型)を認めた.

は, CA19-9が250IU/ml と高值を示した（表 1 )。

腹部超音波検査：膵頭部に $50 \mathrm{~mm}$ 大の腫瘤像を認 め, 主膵管は, 直径 $7 \mathrm{~mm}$ と拡張を認めた。胆㐮は腫大 し, 肝内胆管の軽度拡張も認めた. 第 5 病日, 減黄目 的にて, 経皮経肝胆囊ドレナージ術 (以下, PTGBD) を施行した。

PTGBD 造影：下部総胆管の閉塞像を認め, 同部位 より肝側の総胆管, 肝内胆管に軽度の拡張像を認めた が, 脺管は造影されなかった(図 1).この際, PTGBD チューブより採取された胆汁中のアミラーゼ值は, 380
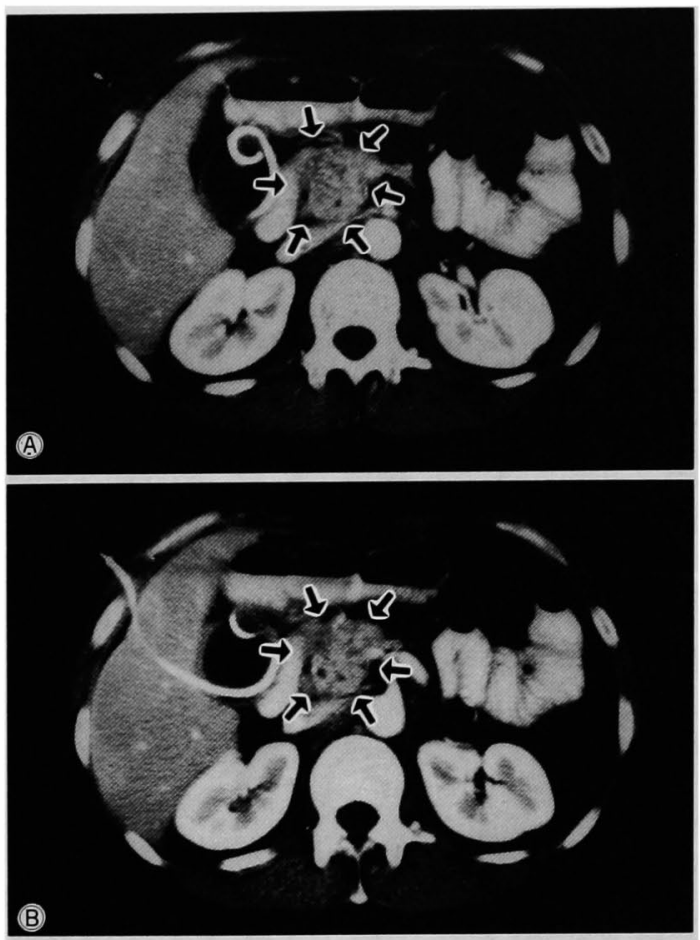

図 3A，B 腹部 CT 検査：膵頭部に周囲が不整に造影 される腫瘍像（最大径 $5 \mathrm{~cm}$ ）を認めた。

$\mathrm{IU} / \mathrm{L}$, 胆汁中の CA19-9值は, $10,000 \mathrm{IU} / \mathrm{ml}$ 以上と高 值を示したが, 胆汁細胞診はClass I であった.

ERCP 検査所見：主膵管と下部総胆管が膵頭部内 で合流し， $3.5 \mathrm{~cm}$ にわたる共通管を形成する，IIa 型膵 管胆管合流異常を認め, 合流部では，胆管，膵管とも に狭窄像がみられ，かつ膵体尾部の主萃管は数珠状の 拡張像を認めた（図２）。

腹部 CT 検査：膵頭部に内部が不均一に造影される 径 $5 \mathrm{~cm}$ 大の腫瘤像を認めた。体尾部の主萃管は拡張 し，胆囊の腫大を認めたが，胆囊には腫瘍性病変はみ られなかった（図 3A, B).

腹部血管造影：腹腔動脈造影動脈相にて膵頭部に一 致して，無血管野を示す腫瘤陰影を認め(図 4A)，上 腸間膜動脈造影の静脈相では，門脈本幹に圧排像を認 め, 腫瘍の門脈への浸潤が強く疑われた（図 4B).

以上より膵管胆管合流異常に合併した膵頭部癌と診 断し，同年3月10日，手術を施行した。

手術所見：膵頭部には硬い腫瘤（直径 $5 \mathrm{~cm}$ 大）を触 れ，膵体尾部はびまん性に硬く触知したが，肝転移お よび腹膜播種, 腹腔内リンパ節の腫脹は認めなかった. 術中, 腫怚の門脈浸潤ありと判断し, 門脈合併切除 (全 

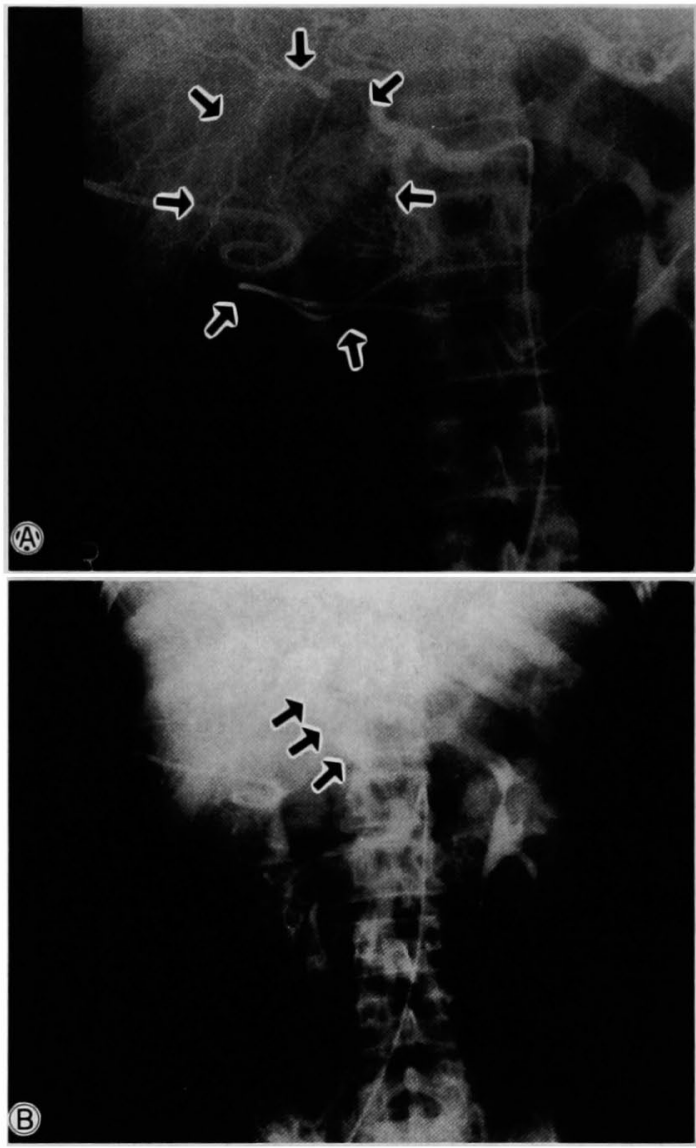

図 4 腹部動脈造影

A. 腹腔動脈造影一動脈相：膵頭部に無血管野を示す 腫瘤陰影を認めた。 B. 上腸間膜動脈造影一静脈相：門 脈本幹に圧排像を認めた。

長 $5 \mathrm{~cm}$ ）を伴う膵頭十二指腸切除術（R2）を施行した. 術中所見は $\mathrm{TS}_{3}, \mathrm{~S}_{2}, \mathrm{RP}_{0}, \mathrm{CH}_{2}, \mathrm{DU}_{1}, \mathrm{PV}_{2}, \mathrm{~A}_{0}, \mathrm{PL}$ $(-), \mathrm{P}_{0}, \mathrm{H}_{0}, \mathrm{~N}_{1}$ で, Stage IVa の診断にて，根治度 Bの手術であった。

摘出標本：膵頭部に $5.0 \times 3.0 \times 3.5 \mathrm{~cm}$ 大の結節型 腫瘍を認めた。非腫崵部はびまん性に硬化し，慢性膵 炎の状態を呈していると考えられた。主膵管と胆管と の合流部は,腫瘍内にあり,確認することはできなかっ た。

病理学的検査所見：腫瘍は膵頭部に発生した高分化 型管状腺癌 (図 5A) で，腫瘍の門脈浸潤は病理学的に は陰性で, No. 13b $\left(\mathrm{n}_{1}\right)$ のリンパ節に転移を認めた. また，非腫瘍部の主膵管上皮には，炎症細胞浸潤と非 乳頭状過形成性変化を認めたが異型細胞を認めず，胆
管上皮にも軽度の炎症を認めるのみで明らかな異型細 胞を認めなかった (図 5B,C). 病理組織学的所見を要 約すると, 高分化型管状腺癌, intermediate type, INF $\beta, \mathrm{ly}_{2}, \mathrm{v}_{2}, \mathrm{ne}_{2}, \operatorname{mpd}(-), \mathrm{s}_{2}, \mathrm{rp}_{0}, \mathrm{ch}_{1}, \mathrm{du}_{0}, \mathrm{pv}_{0}$, $\mathrm{a}_{0}, \mathrm{pl}(-)$, pw $(-)$, bdw $(-)$, ew $(-), \mathrm{n}_{1}(+)$ (No. 13b) であった.

術後経過: 術後 2 年 6 力月経過するも, 再発の兆候 なく存命中である。

\section{考 察}

膵管胆管合流異常と胆道系覀性腫瘍との合併例は諸 家により報告され，胆管内への膵液逆流が発症の引き

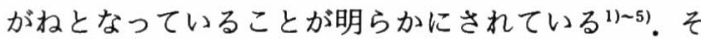
の発癌のメカニズムとして, 膵液の胆管内逆流により, 脺液中の醉素である phospholipase A が胆汁中の lec ithinを加水分解し，この反応により産生された lysolecithin が，攻撃因子として胆道系粘膜に障害を 与え，上皮細胞の破壊と再生を繰り返す過程が考えら れている6!.

一方, 膵管胆管合流異常, および先天性胆道拡張症 と膵頭部癌との合併例の報告は, われわれが検索し得 た範囲では，本症例を含めて11例と胆道系悪性腫瘍の 報告に比較し少ないて 7 15)。

現段階では症例が少なく, 膵管胆管合流異常と膵癌 発生との関係は明らかにされていない.しかし, 吉武 ら は, 発癌の因子として，1）膵管内逆流胆汁の長期 暴露 (膵液䙪滞) に伴う発癌の可能性，2）膵管胆管合 流異常に伴う慢性膵炎によって惹起される膵管上皮の 再生過程における発癌の可能性などをあげている.

膵管胆管合流異常では, 通常, 圧勾配の高い膵液が 胆道系に逆流する状態にあるが，吉武ら》は何らかの 原因（食後の胆囊收縮など）によって, 胆管内圧が上 昇し，胆汁が膵管内に逆流し，膵管上皮細胞を障害す る可能性を述べている.

慢性脺炎に伴う膵管上皮の過形成が発癌に関与して いる可能性は以前より指摘されており, 諸家により萃 癌症例では膵管上皮過形成が高率に認められると報告 されている ${ }^{16117)}$. 小塚ら ${ }^{16)}$ は, 膵管上皮の過形成を非乳 頭状, 乳頭状, 異型過形成の 3 つに分類し, 非乳頭状 過形成 $\rightarrow$ 乳頭状過形成 $\rightarrow$ 異型過形成 $\rightarrow$ 脺癌の組織移行 を認めたとしている。膵管胆管合流異常は, 胆汁と膵 液の相互の逆流防止を制御する括約筋機能の異常であ り，膵炎を発症しやすい病態ではあるが，膵管䏣管合 流異常の慢性膵炎の合併頻度は，13～33\% と報告され ており ${ }^{18) ~ 22)}$, 感染や副膵管の存在などの他因子の関与 

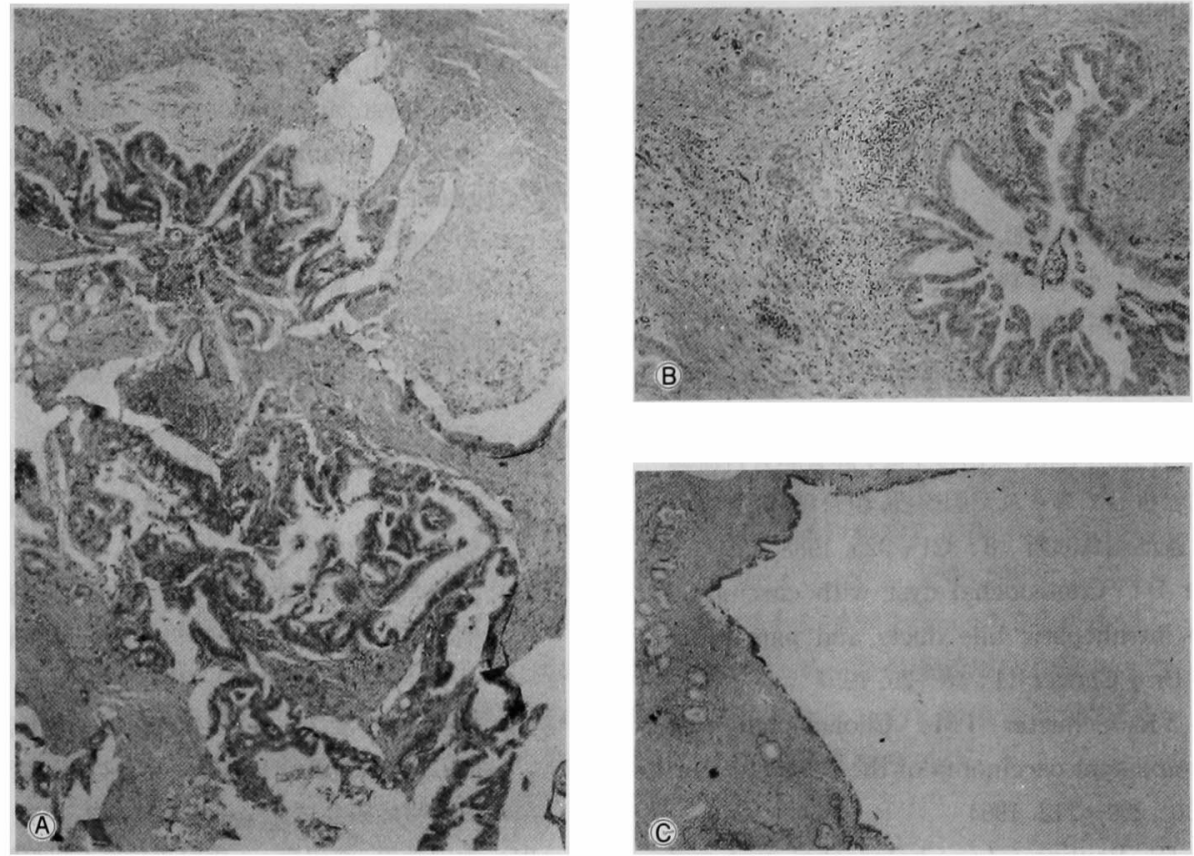

\section{図 5 病理組織学的所見}

A. 腫瘍部：高分化型管状腺癌を認めた $(\mathrm{HE}$ 染色, $\times 40)$ ．B，主膵管：膵管上皮に再 生性変化を認め, 周囲膵組織には慢性炎症所見を認めた $(\mathrm{HE}$ 染色, $\times 40) . C$. 総胆管： 慢性炎症所見を認めるも, 異型細胞を認めなかった $(\mathrm{HE}$ 染色, $\times 20)$.

が,膵炎を併発する際に重要であると考えられている。 加えて, 膵管胆管合流異常に膵癌を合併した症例の報 告と膵炎合併症例との間に発生頻度の差があること も, 発癌には膵炎以外の他因子の関与の可能性が考え られる。

膵管胆管合流異常の病態下では, 逆流胆汁と慢性膵 炎の両者は独立した因子ではなく,相互に深く関与し, 発癌に関与している可能性も十分考慮に入れる必要が ある。

本症例では, IIa 型の膵管胆管合流異常を認め ${ }^{22)}$, 主 膵管と総胆管の拡張は軽度であった. 腫瘍は膵頭部に 位置し，共通管，膵管，および胆管の合流部を巻き込 む形態をとっていた，膵実質組織は，萎縮し高度なリ ンパ球の浸潤を認め，慢性膵炎の所見を呈したが，腫 瘍の主膵管圧排に伴う膵炎像なのか, 腫瘍発生以前か ら慢性膵炎が存在したのかは不明であるが，膵管上皮 には過形成変化を認めるものの, 明らかな異型を示す 上皮細胞の存在を認めなかった，本症例では，膵管胆 管合流異常に偶発的に膵頭部癌が合併した可能性も否 定できないが，実験発癌や両者の合併症例の累積を待 ち,さらなる検討を要すると考えられる。
結語

本症例は, 膵頭部癌と膵管胆管合流異常との合併症 例であり, 両者の関連性に関し, 興味ある症例である と考え報告した。また，膵癌の合併例がみられること から, 膵管胆管合流異常では, 膵疾患の精査も念頭に おく必要があると考えられた。

\section{文献}

1）戸谷拓二, 渡辺泰宏, 藤井 正他：膵・胆管合流異 常および先天性胆道拡張症における癌発生. 胆と 膵 $6: 525-535,1985$

2) 戸谷拓二：胆道拡張症と癌化. 消病セミナー, 27 , へるす出版，東京，1987，p129-151

3）杉原順一, 関田幹雄, 斎藤洋一：膵胆管合流異常と 癌. 胆と萃 $3: 487-495,1982$

4）黑田 慧, 永井秀雄, 森岡恭彦：膵胆管合流異常と 癌合併. 胆と萃 $9: 1191-1203,1988$

5) 羽生富士夫, 大橋正樹, 大井 至 : 胆道奇形と胆道 癌一膵・胆管合流異常一, 胆と脺 $2: 1637-1644$, 1981

6) Neiderhiser DH, Morningstar WA, Roth HP, et al: Absorption of lecithin and lysolecithin by 
the gallbladder. J Lab Clin Med 82: 891-897, 1973

7）吉武英子, 平田公一, 吉田和義他：膵·胆管合流異 常に膵頭部癌をともなった 1 例. 日消外会誌 19 ： $59-62,1986$

8）三本松微, 横山嬢太郎, 遠藤昌夫地：膵管胆管合流 異常と膵癌. 小児外科 $17: 1361-1366,1985$

9）岡田節雄，田中 聰：胆蘘癌と脺蔵癌の異時性重 複癌を合併した脺管胆管合流異常症の 1 例。手術 46 : 1903-1909, 1992

10）上田順彦, 永川宅和, 太田哲生他：膵管胆管合流異 常症に合併してみられた胆漖癌, 胆管癌, 膵管癌の 1 例. 腹部画像診断 $8: 321-325,1988$

11) Dexter D: Choledochal cyst with carcinoma of the intrahepatic bile ducts and pancreatic ducts. Br J Cancer 11: 18-25, 1957

12) Kelly $T R$, Schueter $T M$ : Choledochal cyst with coexistent carcinoma of the pancreas. Am Surg $30: 209-212,1964$

13) Binks JB. Pauline GJ : Choledochal cyst and carcinoma of the pancreas in a boy of fifteen years. Aust NZ J Surg 40: 42-44, 1970

14) Wood CB, Baum $M$ : Carcinoma of the head of the pancreas developing in a young woman with a chledochal cyst. Br J Clin Pract 29: 160
$-162,1975$

15) Deeg HJ, Rominger JM, Shah AN : Choledochal cyst and pancreatic carcinoma demonstrated simultaneously by endoscopic retrograde cholangiopancreatography. South Med J $73: 1678-1680,1980$

16）小塚貞雄：膵癌の発生母地一臨床病理から一, 胆 と脺 $2: 1657-1663,1981$

17）小西陽一：膵癌の発生母地一実験病理から一, 胆 と膵 $2: 1665-1669,1981$

18）土㞳文武，大井 至，竹内 正地：膵·胆管合流異 常と膵炎一主として脺管像から一. 胆と脺 3 ： 505-513, 1982

19）富田志郎，須藤俊之，松川昌勝他：脺胆管合流異常 例の脺管像扔上び脺病変の検討。日脺䑏病研会フ ロシーディングス $11: 154,1981$

20）宮田 晋, 啮江 正, 山口薄正他：膵疾思からみた 膵・胆管合流異常と膵炎一主として膵管像から一。 日脺蔵病研会プロシーディングス $11: 164,1981$

21）太田哲生, 清水康一, 東野義信他：胆管膵管合流異 常および脺管疮合不全に起因すると思われる墙炎 症例の検討. 日膵臓病研会プロシーディングス $11: 158,1981$

22）古味信彦：膵管胆道合流異常一再発見から病型分 類まで。日臨外医会誌 $53: 481-497,1992$

\title{
A CASE OF ANOMALOUS ARRANGEMENT OF PANCREATOBILIARY DUCTS ASSOCIATED WITH A CARCIONOMA OF THE PANCREAS HEAD
}

\author{
Kenichi TAZAWA, Yuji KASHIMA, Satoshi SUZUKI, \\ Katsuki MUNEOKA and Renichiro SATOH \\ Department of Surgery, Koseiren Akita-Kumiai General Hospital
}

A 48-year-old woman was admitted to the hospital because of upper abdominal pain and general iching. Image findings showed a cancer in the head of pancreas associated with anomalous arrangement of the pancreatobiliary duct (Ila type). To decrease jaundice, percutaneous transhepatic gallbladder drainage (PTGBD) was performed. Bile juice amylase count taken by this drainage method was $380 \mathrm{IU} /$ $\mathrm{L}$, and bile juice CA19-9 was over 10,000 IU/L. Bile juice cytology by this drainage method showed Class I. Pancreatoduodenectomy with a partial resection of the portal vein was performed. Histopathologically, the resected specimen of the tumor measuring about $5 \mathrm{~cm}$ in diameter, revealed well-differentiated tubular adenocarcinoma of the pancreas head and regenerative epithelium of the main pancreatic duct with chronic inflammation.

There have been few cases of anomalous arrangement of pancreatobiliary ducts associated with a carcinoma of the pancreas head, and no apparent association between both diseases has been proved as yet. It is proposed that probable coexistence of pancreatic carcinoma should be entertained in the treatment of anomalous arrangement of pancreatobiliary duct. 